\title{
Biocultural approaches to pollinator conservation
}

Article

Accepted Version

Hill, R., Nates-Parra, G., Quezada-Euán, J. J. G., Buchori, D., LeBuhn, G., Maués, M. M., Pert, P. L., Kwapong, P. K., Saeed, S., Breslow, S. J., Carneiro da Cunha, M., Dicks, L. V., Galetto, L., Gikungu, M. G., Howlett, B. G., ImperatrizFonseca, V. L., Lyver, P. O.'B., Martín-López, B., OterosRozas, E., Potts, S. G. and Roué, M. (2019) Biocultural approaches to pollinator conservation. Nature Sustainability, 2 . pp. 214-222. ISSN 2398-9629 doi:

https://doi.org/10.1038/s41893-019-0244-z Available at https://centaur.reading.ac.uk/82035/

It is advisable to refer to the publisher's version if you intend to cite from the work. See Guidance on citing.

To link to this article DOI: http://dx.doi.org/10.1038/s41893-019-0244-z

Publisher: Nature

All outputs in CentAUR are protected by Intellectual Property Rights law, including copyright law. Copyright and IPR is retained by the creators or other copyright holders. Terms and conditions for use of this material are defined in the End User Agreement. 


\section{www.reading.ac.uk/centaur}

\section{CentAUR}

Central Archive at the University of Reading

Reading's research outputs online 


\section{Biocultural approaches to pollinator 2 conservation}

4 Abstract

5 Pollinators underpin sustainable livelihoods that link ecosystems, spiritual and cultural values, and

6 customary governance systems with indigenous peoples ${ }^{\mathrm{a}}$ and local communities (IPLC) across the

7 world. Biocultural diversity is a short-hand term for this great variety of people-nature interlinkages

8 that have developed over time in specific ecosystems. Biocultural approaches to conservation

9 explicitly build on the conservation practices inherent in sustaining these livelihoods. We used the

10 Conceptual Framework of the Intergovernmental Platform on Biodiversity and Ecosystem Services to

11 analyse the biocultural approaches to pollinator conservation by indigenous peoples and local communities globally. The analysis identified biocultural approaches to pollinators across all six elements of the Conceptual Framework, with conservation-related practices occurring in sixty countries, in all continents except Antarctica. Practices of IPLC that are significant for biocultural approaches to pollinator conservation can be grouped into three categories: the practice of valuing diversity and fostering biocultural diversity; landscape management practices; and diversified farming systems. Particular IPLCs may use some or all of these practices. Policies that recognise customary tenure over traditional lands, strengthen Indigenous and Community Conserved Areas, promote heritage listing and support diversified farming within a food sovereignty approach, are among several identified that strengthen biocultural approaches to pollinator conservation, and thereby deliver mutual benefits for pollinators and people.

\footnotetext{
a Here we follow the global norm of using lower case for "indigenous" while recognising the norm in Australia and New Zealand is to use upper case, following Johnson, J.T. et al. (2007) Creating anti-colonial geographies: Embracing indigenous peoples' knowledges and rights. Geographical Research 45 (2), 117-120.
} 
26 Keywords: biocultural diversity, indigenous peoples, local communities, conservation, biodiversity, 27 governance, cultural values 


\section{Introduction}

Pollinators are integral to a good quality of life for people globally, contributing to sustainable livelihoods, maintenance of ecosystem health and function, food production, cultural, spiritual and social values ${ }^{1}$. Inclusive policy for their conservation requires innovative, multiscale assessments that include evidence from science and other knowledge systems ${ }^{2}$. Yet conservation science has often neglected societies' values, world views and knowledge systems and ignored culturally-grounded approaches $^{3}$. In this context, biocultural approaches to conservation, which explicitly build on local cultural perspectives and recognize feedbacks between ecosystems and quality of life, have emerged as key to the necessary inclusivity ${ }^{4}$. Biocultural approaches are underpinned by the concept of biocultural diversity, which recognises that culture and biodiversity are linked and may be mutually constituted ${ }^{5}$. Indigenous peoples and local communities (IPLCS) are integral to the biocultural diversity that has developed in ecosystems over millennia, including large areas of the globe, many with high biodiversity, over which IPLCs have management responsibility ${ }^{6}$. The Intergovernmental Science-Policy Platform on Biodiversity and Ecosystems Services (IPBES) is promoting inclusivity in assessments through the IPBES Conceptual Framework ${ }^{5}$, their valuation approaches ${ }^{7}$, and by providing space for context-specific culturally-grounded ways of assessing nature's contributions to people $(\mathrm{NCP})^{8}$. In this paper, we provide the first global analysis and review of current literature about biocultural approaches to pollinator conservation, drawing on and augmenting work undertaken for the first IPBES assessment ${ }^{9}$.

For the first time in any global environmental assessment, the IPBES global pollination assessment included indigenous and local knowledge (ILK) ${ }^{b}$. This incorporation of ILK focused on the contributions of pollination and pollinators to two elements of the IPBES Conceptual Frameworkgood quality of life and nature's contributions to people ${ }^{10}$. For this paper, we analyse biocultural approaches, based on ILK, according to all six elements of the IPBES Conceptual Framework (CF) ${ }^{5}$ (Figure 1). We focus on the knowledge of IPLCs, both groups identified essentially by their (multiscalar) linkages with their traditional territories (see Methods, Box 1). Our analysis demonstrates that practices of IPLCs that are significant for pollinator conservation can be grouped into three categories: (1) the practice of valuing diversity and fostering biocultural diversity; (2) landscape management practices; and (3) diversified farming systems. Particular IPLCs may use some or all of these practices. Seven policies to strengthen these approaches are presented, followed by concluding comments about implications for future science and policy. Methods for analysis, literature review and (self)-identification of IPLCs are presented at the end of the article.

\section{Results of the Analysis}

All six elements of the IPBES CF are presented in Figure 1(a); and Figure 1 (b) presents the analysis of IPLCs' biocultural approaches to pollinator conservation into these elements, which includes

\footnotetext{
${ }^{\mathrm{b}}$ Indigenous and local knowledge is defined here in accordance with Diaz et al. 2015 as "A cumulative body of knowledge, practice and belief, evolving by adaptive processes and handed down through generations by cultural transmission, about the relationship of living beings (including humans) with one another and with their environment. It is also referred to by other terms such as, for example, Indigenous, local or traditional knowledge, traditional ecological/environmental knowledge (TEK), farmers' or fishers' knowledge, ethnoscience, indigenous science, folk science."
} 
recognition of drivers of unsustainable practices for pollinators which are evident among some IPLCs. The arrows between the elements reflect influences and interactions ${ }^{5}$ which are not further described here.

Figure 1 (a) IPBES Conceptual Framework ${ }^{5}$ and (b) analysis of biocultural approaches to pollinator conservation according to this Conceptual Framework

\section{Pollinators, pollination and good quality of life}

Pollinators and plant-pollinator interaction networks make vital contributions to IPLCs' quality of life, in both subsistence and market economies, as part of socio-cultural heritage, identity, and social relations ${ }^{11}$. Pollinators, primarily bees, and their products, such as honey and wax, provide a direct source of income, food and medicines. Beekeeping provides a critical anchor for rural economies because: (1) minimal investment is required; (2) diverse products can be sold; (3) land ownership or rental is usually not necessary; (4) nutritional and medicinal benefits derive; (5) timing and location of activities are flexible; and (6) links to ILK and traditions are usually numerous ${ }^{12}$. Recovery of stingless beekeeping for rural livelihoods, with diverse species and techniques, is currently underway globally, particularly in tropical America ${ }^{13}$, India, Africa, Central and South America (Figure 2a) ${ }^{10}$. Honey hunting makes significant contributions to some IPLCs, providing vital sustenance and deep connections with quality of life (Figure 2b). Examples of contemporary honey-hunters include: the forest peoples of Indonesia; Ogiek people in Kenya; and Xingu people in Brazil ${ }^{11}$. The collection of entire bee colonies means that high protein components such as brood, royal jelly and pollen form important dietary constituents ${ }^{14}$.

Figure 2 Global patterns of the contribution of biocultural approaches for pollinators and pollination to quality of life, from studies/sites identified in the analysis: (a) beekeeping; (b) honey hunting; (c) Intangible Cultural Heritage listed as globally significant; (d) Cultural and Mixed Sites inscribed on the World Heritage List (WHL) with significance for pollinators

Pollinators' roles in rituals, dances, myths and legends of IPLCs are recognised as globally significant through inclusions in the Intangible Cultural Heritage of UNESCO (Figure 2c). Examples of Intangible Cultural Heritage that rely on pollinator-dependent resources include knotted bag-making by forest peoples of Papua, and barkcloth-making by the Baganda people in Uganda. World Heritage sites that celebrate pollinators are numerous. The World Heritage List is divided into sites listed for their cultural heritage; those listed for their natural heritage; and those that have both cultural and natural heritage, known as "mixed sites". Virtually all natural sites protect pollinators and many cultural and mixed sites protect and celebrate biocultural linkages between people and pollinators (Figure 2d). Examples of sites that recognise biocultural approaches include the Coffee Cultural Landscape of Colombia, and the Osun Sacred Grove protected by Yoruba peoples near Osogbo, Nigeria. The Agave Landscape in Mexico recognizes biocultural interactions with this bat-pollinated plant used since at least the 16th century to produce tequila spirit, and for at least 2,000 years to make other fermented drinks, fibre and cloth. 
108 IPLCs develop and use anthropogenic assets, particularly technologies for honey-hunting and beekeeping ${ }^{15}$ (Figure $1 \mathrm{~b}$ ), that underpin the good quality of their lives. Honey hunters manufacture ladders in Ethiopia ${ }^{16}$ and ropes from lianas in India ${ }^{17}$ for tree-climbing. In Nepal, the Apis dorsata laboriosa honeycombs on cliffs are collected using handmade rope ladders and long sticks known as tangos ${ }^{18}$. Diverse techniques among IPLCs for construction of bee hives have been reported across Europe (e.g. tree-trunk hives ${ }^{19,20}$ ); in Asia (e.g. clay, cow-dung, bamboo, rafter and log hives ${ }^{21-23}$ ); and in west, east and north Africa (e.g. hives made from cane lined with leaves, and woven baskets covered with mud and dung ${ }^{24-26}$ ). In Meso-America, indigenous peoples us hollow logs and clay pots to keep stingless bees ${ }^{13}$.

In France and Spain, anthropogenic assets include traditional swarming methods, harvest and honey extraction techniques, and diverse smokers ${ }^{19}$. Pest management technologies include: use of cow dung (effective against wax moth, wasp, lizard); polythene sheets to protect against lizards and tree frogs in Nepal and India ${ }^{27}$; and chestnut tree-trunk hives to repel wood parasites in Europe ${ }^{19}$. In Morocco, hives are smoked with certain plants that inhibit Varroa spp. mite and placed near plants from which bee-produced propolis has mite-inhibiting effects ${ }^{26}$. Bee wax is a vital asset among many IPLCs, valued for its adherent and hydrophobic properties and used to create non-slip rope, putty, glue, waterproofing, and in the construction and repair of objects ${ }^{28}$. Examples include its use for arrow cement in Bolivia; to soften skins, and make jewelry in Africa; and to make hunting tools, firesticks (thumpup) and didgeridoos, a traditional musical instrument, in Australia ${ }^{10}$.

\section{Biocultural pollinator institutions and governance}

IPLCs' governance and institutional arrangements are central to biocultural approaches to pollinator conservation (Figure 1b). Governance systems consist of actors (individuals and organisations), institutions (formal and informal rules and norms) and multi-level interactions (across scales and between organisations and institutions) ${ }^{29}$. Actors in biocultural governance systems often include actual pollinators, as IPLCs attribute authority to many spirits who are pollinators, including birds, bats, butterflies, bees and other insects ${ }^{10}$.

Customary institutions that assign rights and tenures, and link people to pollinator resources, are common in biocultural approaches. Trees that have bees nesting on them are often owned and rights inherited in Indonesia. Land tenure systems are often multi-layered, for example in the Philippines people can have tenure rights to communal, corporate and individual lands ${ }^{30}$. These overlapping rights enable access to pollinators and pollination resources with sets of checks to ensure conservation.

However, multilevel interactions highlight risks to these biocultural approaches, arising from lack of recognition of customary tenure and other rights at the nation-state level. Nevertheless, Ogiek honey-hunters recently won the case ACHRP vs Republic of Kenya App. No. 006/2012 in the African Court of Human and Peoples' Rights. The judgement recognised their rights to settle in the Mau forest, their role in protecting it and their right to reparations from the Kenya government for forced 
evictions $^{31}$. Nation-state level governance influences how and whether the expansion of agriculture occurs at the expense of pollinators' habitat and NCP ${ }^{32}$. Often the decline of pollinators and the decline of IPLCs' knowledge and governance systems that contribute to the diverse multi-functional agriculture that maintains pollinators occurs simultaneously ${ }^{33}$.

\section{Drivers of change}

Many IPLCs report pollinator and pollination declines associated with expansion of industrial forestry and agriculture into their traditional lands, driving habitat loss and degradation, and replacing biodiverse habitat with monocultures ${ }^{11}$. For example, coffee monoculture results in the destruction of wintering habitat for migratory birds ${ }^{34}$ in South America and the reduction of honey in Ethiopia (Kechifo people) and India (the Kogadu) ${ }^{16}$. Honey hunters in India and Indonesia also note that forest fires and forest loss cause declines in the arrival of swarms and the following honey extraction ${ }^{11,35}$. Furthermore, national laws and development projects focused on agricultural production, rural development and nature conservation have led to breakdown of traditional tenure systems and fragmentation of governance arrangements that are vital to shifting agriculture and other practices that protect pollinators, such as in the Bolivian Amazon and the northern Philippines ${ }^{30,33}$. Traditional farming systems are undervalued relative to commercial, industrial and trade-oriented resource exploitation of the same spaces, despite the ecosystem services that traditional farming protects. Poverty leads to out-migration of farmers searching for opportunities elsewhere and erosion of traditional farming/ecosystem management practices that co-generate landscapes and sustain biocultural diversity ${ }^{36}$.

Pesticides have often been seen as the cause of declines in pollinators. Several indigenous communities have noted a link between pesticide use and declines of colonies and honey in Burkina Faso, Korea, parts of Brazil, Paraguay, Uruguay, Argentina and India ${ }^{10}$. Pear producers in Hanyuan County in China have adopted hand-pollination as insect pollinators have disappeared due to the use of herbicides and pesticides ${ }^{37}$. Invasive species, such as African and European bees, are recognised by IPLCs in South and Central America as driving declines in native pollinators and their products, including stingless bee honey ${ }^{10}$.

Reviews across Mexico, Costa Rica, Brazil, Africa and Asia indicate that stingless beekeeping is disappearing in some areas $^{38-40}$ while stingless bee breeding is increasing in others as a tool for development $^{41}$. In the Yucatan, the most important populations of species of stingless bees, like Melipona beecheii, are in the hands of Mayan farmers, as large forest trees have disappeared ${ }^{42}$. Loss and decline of the stingless bees is linked with a loss of traditional knowledge and practices such as ethnomedicine (use of honey), cosmogony, and handcraft (using cerumen) ${ }^{10}$. Serious and sudden loss of language and traditional practices of the Ogiek people (Kenya) has resulted from being excluded from rock- and ground-nesting bees as their traditional forests have become part of Lake Nakuru National Park ${ }^{11}$.

Substantial research on ILK has identified its ongoing loss and decline, as well as resilience, as smallscale societies became more integrated within nation-states and market economies. Losses extend to declines in knowledge about pollination-related agricultural and management practices, for 
example of plants that attract pollinators ${ }^{43}$. Amongst Māori, the movement of people away from communities during the rural-urban migration of the 1950s contributed to the loss of ILK relevant to pollination ${ }^{11}$. Regrettably, IPLCs in different parts of the world also frequently suffer lack of access to food, and extreme poverty, which compromises their relationships with ecosystems, and can drive rapid changes in ecosystem function ${ }^{11}$. Pollinators can themselves become threatened as IPLCS experience scarcity of wild food resources. For example, large flying foxes (Pteropus vampyrus natunae) in Kalimantan, Indonesia, are threatened by over-hunting for food ${ }^{44}$.

\section{Systems of life}

Anthropogenic and natural drivers of change in turn influence the systems of life on which IPLCS depend (Figure 1). Biocultural understandings of systems of life recognise humans and their languages as critical to both co-creating and understanding biodiversity. Language holds culturally specific knowledge of local biodiversity, ethnobiological knowledge, as well as knowledge about traditional resource use, management practices and taxonomy. Thus, ethnoscience for ascribing names to groups of animals and to individual species is prominent across the world. Morphological, ecological and behavioural characteristics as well as seasonal occurrence are used by IPLCs to classify different plant and animal species, resulting in unique understandings of the systems of life ${ }^{45,46}$.

The ILK of bee pollinators' systems of life is particularly deep. For instance, detailed accounts of names, nests and anatomy of stingless bees can be found in many cultures ${ }^{10,11}$. Stingless bee honey and cerumen were used as currency, tribute, medicine and in ceremonies in Mesoamerican civilizations $^{38}$. The people from the Yucatan have specific names in Mayan language for the seventeen species of stingless bees found in this region of Mexico and of guardian deities for the bees ${ }^{38,47}$. Accounts of twenty-three named ethnospecies exist among the Hoti people in Venezuela; twenty-five among the Tatuyo, Siriano and Bara peoples of Colombia; thirteen among the GuaraniMbyá people of Argentina, Brazil and Paraguay; around forty-three among Nukak people of northwest Amazon in Colombia; forty-eight among the Enawenê-Nawê people; and fifty-six among the Gorotire-Kayapó in the Brazilan Amazon ${ }^{46,48-51}$. Gorotire-Kayapó, as well as many other indigenous peoples, understand the nest architecture, development and anatomy of stingless bees in detail $^{52}$ (Fig. 3).

Figure 3 Drawings by J.M.F. Camargo ${ }^{52}$, marked with the Kayapó names of the different anatomical structures of a bee (left) and ontogenetic stages of bee development (right). Reproduced with permission.

\section{Nature's contributions to people}

Nature's contributions to people (NCP) include all the contributions, both positive and negative, of nature (i.e. systems of life) to quality of life for people ${ }^{8}$. NCP are created through interactions between systems of life, anthropogenic assets, and institutions and governance. The NCP approach explicitly recognises that a range of views exist about the extent to which 'humans' and 'nature' can 
233 be separated ${ }^{8}$, and provides both a generalizing perspective with 18 categories of NCP; and a

234 context-specific perspective that is more typical of IPLCs' approaches. The context-specific

235 perspective is recognised as potentially producing bundles or groups that follow from distinct lived

236 experiences such as farming, or hunting and gathering. Our analysis identified three such bundles or

237 groups that are considered NCP as part of, and ways to foster, biocultural approaches to pollinator

238 conservation: (1) the practice of valuing diversity and fostering biocultural diversity; (2) landscape

239 management practices; and (3) diversified farming systems.

Figure 4 Landscape management practices ( $a$ and $b$ ) and diversified farming systems ( $c$ and $d)$, based on Indigenous and Local Knowledge (ILK), that are part of and foster pollinators' roles in Nature's Contributions to People (NCP)

The practice of valuing diversity in itself is a key aspect of ILK ${ }^{53}$. Many IPLCs favour heterogeneity in land-use as well as in their gardens, tend to the conservation of nesting trees and flowering resources for bees, butterflies and other pollinators, name and classify a great range of wild bees, observe their habitat and food preferences. Through these activities they contribute to maintaining, fostering and co-creating an abundance and, even more importantly, a wide diversity of bee and other pollinators and animal pollination-dependent biota ${ }^{9,10}$.

Seven landscape management practices identified as part of, and ways to foster, NCP occur through much of the world, and particularly the tropics. These practices include: (1) actions to foster pollinator nesting resources including in houses, forests and landscapes; (2) mental maps and animal behaviour knowledge related to pollinators and their resources; (3) totemic and/or spiritual relationships between people and pollinators, requiring kinship obligations of reciprocity, respect and care with pollinators and their habitat; (4) taboos and traditions that protect pollinator habitat, including prohibitions against felling bee-hive trees and forest patches; (5) manipulation of pollinator resources in landscapes, including through seasonal rotations for prolonged harvests and habitat patch management; (6) use of biotemporal indicators (observed changes in biological processes over time) to trigger management of pollinators and pollinator resources, including using birds and flowering to signal the time for burning vegetation and to harvest honey; and (7) management of fire to stimulate pollinator resources by increasing floral resources ${ }^{10}$ (Figure $4 a, b$ ).

Three types of diversified farming systems based on ILK, scattered across the globe, were identified as part of, and ways to foster NCP (Figure $3 \mathrm{c}$ and d). Evidence is accumulating that commodity agroforestry, practiced by IPLCs and resulting in a landscape matrix of fragments of high-biodiversity native vegetation amidst the agricultural crop, both produces food and maintains pollination services ${ }^{54}$. Home Gardens, capitalised to distinguish those characterised by producing a wide diversity of foods and medicinal plants, display complexity and multi-functionality, and provide habitat for a great diversity of pollinators ${ }^{55}$. Shifting cultivation (seasonal rotation of crops, trees, animals and intercropping) demonstrates diverse interdependencies with pollinators and remains important in many regions, particularly through the tropical world ${ }^{56}$. The traditional Mayan Milpa 
276 shifting cultivation produces a patchy landscape with forests in different stages of succession with a

277 diverse array of plants, nearly all of which are pollinated by insects, birds and bats ${ }^{57}$. Some of these

278 relationships between pollinators and IPLCs have been recognized and protected as Globally

\section{Seven policies to support biocultural approaches to pollinator} conservation

IPLCS across the globe continue to practice many successful biocultural approaches to pollinator conservation. Seven policies are identified that will strengthen biocultural approaches in-situ, as a useful adjunct to the "principles of biocultural approaches to conservation" that provide guidance for conservation interventions ${ }^{4}$. These policies are: (1) requiring prior informed consent for conservation and development; (2) securing customary tenures; (3) strengthening Indigenous and Community Conserved Areas (ICCAs) and other traditional governance that support pollinators; (4) supporting knowledge co-production; (5) promoting heritage listing; (6) fostering livelihoods based on bee-keeping; and (7) promoting food sovereignty.

291

International law supports requiring prior informed consent for conservation and development projects $^{58}$, and similar requirements in some nation-state legislation have protected pollinators. For example, the Forest Rights Act in India has secured access to forests by honey hunters, and kept alive their ILK and practices for fostering bees ${ }^{35}$. Indigenous Protected Areas in Australia required prior informed consent for their creation, and have protected culturally-significant pollinationdependent fruit, their bird and bat pollinators, and their habitats ${ }^{10}$.

Securing customary tenures has proven effective in combating the erosion of traditional management practices that protect pollinators and their habitats. For example, a study of 80 forest commons in 10 countries across Asia, Africa, and Latin America showed that larger forest size and greater rule-making autonomy at the local level produces high carbon storage in trees, thereby protecting the flowers of those trees for pollinators and presumably also the pollinators ${ }^{59}$. Nevertheless, legal means of securing customary tenures need to fully respect the local customary institutions-some legal regimes have imposed a new set of external agents that have been detrimental to social and cultural values ${ }^{60}$.

Strengthening ICCAs is a critical policy agenda that is gaining momentum through the program of work on protected areas under the Convention on Biological Diversity. ICCAs consist of socialecological systems voluntarily conserved by IPLCs through customary laws and traditions. Such areas range in size from $<1$ ha sacred groves in India to $>30,000 \mathrm{~km}^{2}$ indigenous territories in Brazil, and are associated with the protection of links between biodiversity and wildlife that ensure pollination $^{61}$. Governance evaluation provides a means to identify key actions to strengthen the traditional governance arrangements (councils of elders, clan or tribal chiefs, village assemblies) that protect pollinators. 
317 Supporting knowledge co-production activities among farmers, indigenous peoples and scientists

318 has led to numerous improvements in livelihoods and in turn helped to preserve pollinators. For

319 example, community ethno-entomological collections empower traditional knowledge of the

320 difference between insects, and their habitats, of how to foster resources for pollinators, and

321 thereby build synergies with science and ILK ${ }^{62}$. Participatory evaluation of pollinator-friendly farming

322 practices has been used by the Food and Agricultural Organisation of the United Nations (FAO) as an

323 effective framework for co-producing knowledge between scientists and farmers ${ }^{63}$. Biocultural

324 approaches to monitoring that create space for meaningful local metrics, while supporting cross-

325 scale linkages with scientific indicators of status and trends in pollinators, are critical to long term

326 evaluation and adaptive management by IPLCs ${ }^{2}$.

Promoting heritage listing-using international instruments including the Convention Concerning the Protection of the World Cultural and Natural Heritage, the Convention for the Safeguarding of the Intangible Cultural Heritage, and the Globally Important Agricultural Heritage Systems-can bring global support for biocultural approaches to pollinator conservation. The Intangible Cultural Heritage List promotes understanding of practices which are listed-for example the protection of traditional knowledge of Totanac people, which includes agroforestry systems that protect pollinators and stingless beekeeping. World Heritage listing brings international attention to situations and drivers that threaten the sites listed, and their important natural and cultural attributes.

Fostering livelihoods based on beekeeping can overcome many barriers to effective pollinator protection when they are able to link: (1) customary economies (that require ongoing protection of pollinators); (2) markets (that give these products economic significance); and (3) investments from government in accompanying research, market analysis and brokering ${ }^{11}$. Many beekeeping activities are important in both customary and market economies, and benefit from government investments in scientific research and brokering, to ensure that negative impacts-such as high densities of hives resulting in the honeybees outcompeting wild pollinators-are avoided ${ }^{11}$. Certification of organic production, for example, links beekeepers with customers in developed nations prepared to pay for high-value product, and has strengthened ILK and improved incomes for beekeepers in Cameroon ${ }^{64}$.

Promoting food sovereignty helps pollination protection because of its connection with diversified farming systems and management practices that foster diversity and abundance of pollinators and pollination resources ${ }^{65}$. Food sovereignty reorients food systems around local production and agroecological principles, mitigating several of the key risks to pollinators such as landscape homogenisation and the negative impact of agrochemicals, often associated with the expansion of industrial agriculture ${ }^{66}$. With its emphasis on local food systems, food sovereignty provides an effective policy framework for strengthening the diversified farming systems that protect pollinators and pollination (Figure 4). 
Pollinators and pollination have become worldwide heritage and IPLCs' have ancient and recent associations with these organisms, creating rich and unique biocultural manifestations. Different stressors are threatening pollinators and pollination but IPLCS can significantly contribute to maintain pollinators' biodiversity and the derived NCP. The contributions of IPLCS are therefore essential to decision-making and actions for the preservation of these key ecological resources. We consider that the suggested seven policies will strengthen vital ILK while providing ongoing opportunities for education, development and empowerment of the wellbeing of IPLCS and mutual benefits with broader societies. Respecting and recognising IPLCS' rights over natural resources are essential for long term pollinator conservation. Local community-driven conservation initiatives can be successful and should be encouraged.

Further efforts are needed to promote and increase the exchange and integration of knowledge on pollinators and pollination between the scientific world and IPLCS working towards common conservation goals. We conclude that pollination and pollinators can be better preserved by acknowledging IPLCs and working together between ILK and science for sustainable ecosystem governance and management in this time of rapid global change.

\section{Methods}

Indigenous and local knowledge (ILK) held by IPLCs is integral to biocultural approaches to conservation $^{2,4,5}$. Key features for embedding ILK in conservation include IPLCs' customary institutions and practices, and engagement of ILK actors ${ }^{67}$. While the IPBES global pollination assessment did not fully succeed in achieving such engagement, as knowledge-holders and their institutions were not involved in the latter parts of the assessment, several methods, including global and community dialogues in the early phases and tailored literature analyses, ensured a highdegree of rigour in our approach to working with ILK ${ }^{67}$.

An initial review of scientific literature was conducted using a systematic protocol (searching English, Spanish and French literature) with four subsequent steps to enable incorporation and analysis of ILK ${ }^{10}$. First, a global call was issued for indigenous and local knowledge holders from IPLCs and experts who wished to contribute information relevant to pollinators and pollination, to participate in global and community dialogues. Our work respects the recognition by the United Nations that no formal definition of whom are indigenous peoples and/or local communities is needed-selfidentification is the key requirement (Box 1). Indigenous peoples and local communities, IPLCS, display great diversity in their ways of life, including hunter-gathers who practice no recognizable forms of agriculture (but may intensify the populations of some plants and animals); those who modify landscapes for example through use of fire; those who rely on farming domesticated plants and animals; and those who practice diverse combinations of farming, hunting, gathering and managing their landscapes to provide food resources.

Box 1: Who are indigenous peoples and local communities (IPLCs)? Indigenous peoples include communities, tribal groups and nations, who self-identify as indigenous to the territories they occupy, and whose organisation is based fully or partially on their own customs, traditions, and laws. Indigenous peoples have historical continuity 
with societies present at the time of conquest or colonisation by peoples with whom they now often share their territories. Indigenous peoples consider themselves distinct from other sectors of the societies now prevailing on all or part of their territories. The United Nations recognizes that no formal definition of whom are indigenous peoples and/or local communities is needed-self-identification is the key requirement.

Local communities are groups of people living together in a common territory, where they are likely to have face-to-face encounters and/or mutual influences in their daily lives. These interactions usually involve aspects of livelihoods-such as managing natural resources held as 'commons', sharing knowledge, practices and culture. Local communities may be settled together or they may be mobile according to seasons and customary practices. Communities who come together in urban or peri-urban settings around common interests, such as beekeeping, are considered here to be "communities of interest" rather than local communities $^{10}$.

The resultant global and community dialogues provided much-needed information and guidance, and were supplemented by an ILK scoping literature review ${ }^{11}$. Second, an analytical framework was co-developed between ILK-holders and experts to guide the project. Third, literature was prioritised where evidence showed a direct role for ILK holders in representing and validating their own knowledge. A more extensive list of the literature sources can be found online in Chapter 5 of Pollinators, pollination and food production: a global assessment

(https://www.ipbes.net/assessment-reports/pollinators ). Fourth, spatial analysis was undertaken to locate the various national and regional data syntheses and site-specific examples in relation to the themes in the analytical framework. The final steps to enable this analysis involved firstly updating the review with publications since 2015 (the cut-off date for the IPBES pollination report), and heritage sites and elements listed in 2016-17; and secondly re-analysing the data gathered through the dialogues ${ }^{11}$ and literature to respond to all elements of the IPBES CF.

\section{Data availability}

Data for Figures 2 and 4 can be found at https://doi.org/10.25919/5c3d14a45ec49. Several files are available for download, including the spatial data for all the locations on the maps, and the literature or online sources for each of these locations. Data which link the literature/online sources to the locations are also available upon request to the corresponding author, with a brief explanation of why the data is required. These restrictions are in place to protect the privacy of the indigenous peoples and local communities. Source data for Figures 1 and 3 are shown on the captions.

\section{Correspondence}

Correspondence and requests for materials should be address to R.H. ro.hill@csiro.au

\section{Acknowledgements}

We thank the indigenous peoples and local communities globally who provided their knowledge of practices and philosophies underpinning conservation of pollinators and pollination to the hundreds 
of publications that we reviewed for this article. Their contributions to the sustainable use and conservation of biocultural diversity over millennia benefits many peoples globally, and we are deeply grateful. We particularly thank those IPLCs and their partners who participated directly in global and community dialogues about pollination for the IPBES assessment of Pollinators and Pollination in Food Production. Hien Ngo of the IPBES Secretariat and Douglas Nakashima and his team from UNESCO provided wonderful support to these dialogues. We also acknowledge the fine efforts of IPBES to work with ILK in their assessments and their commitments to recognise and respect the roles of IPLCs. We thank IPBES for the opportunity to be involved in the assessment that enabled our team of co-authors to meet one-another and subsequently progress this paper. Each of us would also like to acknowledge and thank our organisations which supported our contributions to this paper. L.V.D. is funded by the Natural Environment Research Council NERC (NE/N014472/1). R.H. is supported through CSIRO Land and Water's Indigenous Futures initiative. We also thank two anonymous referees whose helpful comments improved the paper. We would like to thank Giselle Cristina Aragão of Empresa Brasileira de Pesquisa Agropecuária (Embrapa) and Jacqui Smith of WhiteSpace Design Studio, for their contributions to Figures 1 and 2, 3, 4 respectively.

\section{Author Contributions}

R.H., G.N-P and J.J.G.Q-E coordinated the conceptual design, and together with D.B., G.L., M.M.M., drafted the text of the manuscript. P.L.P. undertook the spatial analysis and prepared the maps, with assistance from R.H. and L.G. in data preparation. All 21 authors contributed to the ideas, evaluation of the literature, review and finalization of the text.

\section{Competing Interests}

461 The authors declare no competing interests.

\section{References}

1 Potts, S. G. et al. Safeguarding pollinators and their values to human well-being. Nature 540, 220-229. http://www.nature.com/nature/journal/v540/n7632/abs/nature20588.html, doi:10.1038/nature20588 (2016).

2 Sterling, E. J. et al. Biocultural approaches to well-being and sustainability indicators across scales. Nature Ecology \& Evolution, doi:10.1038/s41559-017-0349-6 (2017).

3 Bennett, N. J. et al. Mainstreaming the social sciences in conservation. Conserv. Biol. 31, 5666, doi:10.1111/cobi.12788 (2017).

4 Gavin, M. C. et al. Defining biocultural approaches to conservation. Trends Ecol. Evol. 30, 140-145, doi:10.1016/j.tree.2014.12.005 (2015).

5 Díaz, S. et al. The IPBES Conceptual Framework - connecting nature and people. Current Opinion in Environmental Sustainability 14, 1-16, doi:http://dx.doi.org/10.1016/j.cosust.2014.11.002 (2015).

6 Brondizio, E. S. \& Tourneau, F.-M. L. Environmental governance for all. Science 352, 12721273, doi:10.1126/science.aaf5122 (2016).

7 Pascual, U. et al. Valuing nature's contributions to people: the IPBES approach. Current Opinion in Environmental Sustainability 26-27, 7-16, doi:http://dx.doi.org/10.1016/j.cosust.2016.12.006 (2017).

8 Díaz, S. et al. Assessing nature's contributions to people. Science 359, 270-272, doi:10.1126/science.aap8826 (2018).

9 IPBES. Summary for policymakers of the assessment report of the Intergovernmental SciencePolicy Platform on Biodiversity and Ecosystem Services on pollinators, pollination and food 


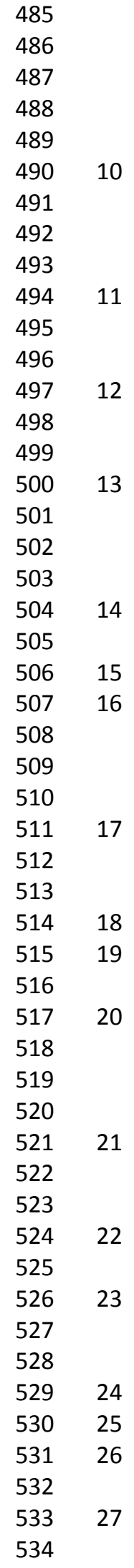




\begin{tabular}{|c|c|c|}
\hline $\begin{array}{l}535 \\
536\end{array}$ & 28 & $\begin{array}{l}\text { Kamienkowski, N. M. \& Arenas, P. Explotación de himenópteros melíferos entre etnias del } \\
\text { Gran Chaco: Una mirada etnobiológica. Memorias XCIMFAUNA, 1-8 (2012). }\end{array}$ \\
\hline 537 & 29 & Hill, R. \& Duncan, J. in Food production and nature conservation: Conflicts and solutions \\
\hline 538 & & (eds I.J. Gordon \& H. Prins) 295-329 (Taylor Francis, 2016). \\
\hline 539 & 30 & $\begin{array}{l}\text { Prill-Brett, J. Changes in indigenous common property regimes and development policies in } \\
\text { the northern Philippines. Politics of the Commons: Articulating Development and }\end{array}$ \\
\hline 11 & & trengthening Local Practices. Conference held July 11-14, 2003. Changmai, Thailand, Onlin \\
\hline 542 & & ttp://hdl.handle.net/10535/11934 (2003). \\
\hline 543 & 31 & Minority Rights Group International. Huge victory for Kenya's Ogiek as African Court sets \\
\hline 44 & & major precedent for indigenous peoples' land rights. (Minority Rights Group International, \\
\hline 45 & & Inline: http://minorityrights.org/2017/05/26/huge-victory-kenyas-ogiek-african-court-sets \\
\hline 46 & & najor-precedent-indigenous-peoples-land-rights/. Accessed 1 October 2017, 2017). \\
\hline 17 & 32 & eddia, M. G., Bardsley, N. O., Gomez-y-Paloma, S. \& Sedlacek, S. Governance, agricultural \\
\hline 48 & & paring in tropi \\
\hline 549 & & 7242-7247, doi:10.1073/pnas.1317967111 (2014). \\
\hline 550 & 33 & Reyes-García, V. et al. Indigenous land reconfiguration and fragmented institutions: A \\
\hline 551 & & historical political ecology of Tsimane' lands ( \\
\hline 52 & & doi:10.1016/j.jrurstud.2014.02.007 (2014). \\
\hline 553 & 34 & cological Interactions \\
\hline 54 & & 158 \\
\hline 55 & & 0213 \\
\hline 556 & 35 & Demps, K., Zorondo-Rodriguez, F., Garcia, C. \& Reyes-Ga \\
\hline 57 & & Local Ecological Knowledge: Honey Collecting with the Jer \\
\hline 558 & & Ecology 40,427 \\
\hline $\begin{array}{l}559 \\
560\end{array}$ & 36 & $\begin{array}{l}\text { ieri, M. A. Globally important agricultural heritage systems: a legacy for } \\
\text { Rome (2011). }\end{array}$ \\
\hline 61 & 37 & land pollination of pears and its implications for biodive \\
\hline 52 & & ental nroter \\
\hline 563 & & ent, Sichuan University, Sichuan, China. Online: \\
\hline 564 & & oollinatorsinitiative.org/jsp/studies/studies.jsp;jsessionid=C8D1A \\
\hline 565 & & 6EFD7B3B94868A7E2AE00BD19D, 2014). \\
\hline 566 & 38 & Quezada \\
\hline 67 & & \\
\hline 568 & 39 & Cortopa \\
\hline 569 & & Apidol \\
\hline 570 & 40 & Villanueva-Gutiérrez, R., Roubik, D. W., Colli-Ucán, W., Güemez-Ricalde, F. J. \& Buchmann, \\
\hline 571 & & L. A Critical View of Colony Losses in Managed Mayan Honey-Making Bees (Apidae: \\
\hline 572 & & Meliponini) in the Heart of Zona Maya. J. Kans. Entc \\
\hline 573 & 41 & Stingless \\
\hline 574 & & Beeke \\
\hline 575 & 42 & González-Acereto, J. A., Quezada-Euán, J. J. G. \& Medina-Medina, L. A. New pers \\
\hline 576 & & stingless beekeeping in the Yucatan: results of an integral programme to rescue and \\
\hline 577 & & ivity. Journal of Apicultural Researc \\
\hline 578 & 43 & Reyes-García, V. et al. Evidence of traditional knowledge loss among a contemporary \\
\hline 57 & & indigenous society. Evol. Hum. Behav. 34, 249-257, \\
\hline 58 & & doi:http://dx.doi.org/10.1016/j.evolhumbehav.2013.03.002 (2013). \\
\hline 58 & 4 & Struebig, M. J., Harrison, M. E., Cheyne, S. M. \& Limin, S. H. Intensive hunting of \\
\hline & & \\
\hline & & 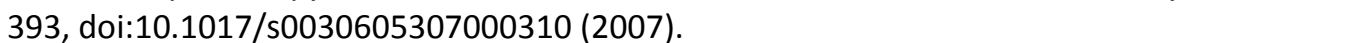 \\
\hline
\end{tabular}




\begin{tabular}{|c|c|c|}
\hline $\begin{array}{l}584 \\
585\end{array}$ & 45 & $\begin{array}{l}\text { Khasbagan \& Soyolt. Indigenous knowledge for plant species diversity: a case study of wild } \\
\text { plants' folk names used by the Mongolians in Ejina desert area, Inner Mongolia, P. R. China. }\end{array}$ \\
\hline 586 & & J. Ethnobiol. Ethnomed. 4, 6, doi:10.1186/1746-4269-4-2 (2008). \\
\hline 587 & 46 & Santos, G. M. \& Antonini, Y. The traditional knowledge on stingless bees (Apidae: \\
\hline 588 & & Meliponina) used by the Enawene-Nawe tribe in western Brazil. J. Ethnobiol. Ethnomed. 4, \\
\hline 89 & & rticle 19 http://www.ethnobiomed.com/content/14/11/19 (2008). \\
\hline 590 & 47 & González-Acereto, J. Acerca de la regionalización de la nomenclatura Maya de abejas sin \\
\hline 91 & & aguijón (Melipona sp.) en Yucatán. Revista de Geografía Agrícola 5, 190-193 (1983). \\
\hline 92 & 48 & Estrada, W. G. Conocimiento siriano y bará sobre las abejas nativas. Comunidad Bogotá \\
\hline 593 & & Cachivera; Mitú, Vaupés., 62 (Convenio SENA-Tropenbos, Colombia, 2012). \\
\hline 594 & 49 & Rosso-Londoño, J. M. \& Parra, A. Cría y manejo de abejas nativas asociadas a producción de \\
\hline 95 & & miel y buenas prácticas apícolas con la empresa de Biocomercio APISVA-Vaupés. Informe \\
\hline 6 & & final de consultoría., (Instituto de Investigación en recursos biológicos Alexander von \\
\hline 597 & & Humboldt, Bogota, Colombia, 2008). \\
\hline 598 & 50 & Cabrera, G. \& Nates-Parra, G. in Memorias III Encuentro IUSSI Bolivariana $59-70$ (1999). \\
\hline 599 & 51 & Rodrigues, A. S. Etnoconhecimento sobre abelhas sem ferrão: saberes e práticas dos índios \\
\hline 600 & & guarani M’byá na Mata Atlântica., ( Escola Superior de Agricultura Luiz de Queiroz, \\
\hline 601 & & Piracicaba, S, Brazil, 2005). \\
\hline 602 & 52 & onal notes on the class \\
\hline & & stingless bees (Meliponinae, Ap \\
\hline 604 & & Brazil. Annals of Carnegie Museum 54, 247-274 (1985). \\
\hline 605 & 53 & da Cunha, M. C. in The Anthropology of Sustainability (eds M. Bright \\
\hline 606 & & 272 (Springer, 2017). \\
\hline 607 & 54 & Perfecto, I. \& Vandermeer, J. The agroecological matrix as alternative to $t$ \\
\hline 608 & & /agriculture intensi \\
\hline 609 & & 1073/nnac $0 \mathrm{c}-1$. \\
\hline 610 & 55 & Agbogidi, O. M. \& Adolor, E. B. Home garde \\
\hline 611 & & Applied Science Reports 1, 19 \\
\hline 612 & 56 & Li, P., Feng, Z. M., Jiang, L. G., Liao, C. H. \& Zhang, J. H. A Review of Swidden Ag \\
\hline 613 & & Southeast Asia. Remote Sensing 6, 1654-1683, doi:10.3390/rs6021654 (2014). \\
\hline 614 & 57 & Perez, E. in Indigenous and Local Knowledge about Pollination and Pollinators associated \\
\hline 615 & & bal Dialogue Workshp (Panama 1-5 December \\
\hline 616 & & erez, M. Carneiro da Cunha, \& M. Roué) 80-87 (UNESCO, 2015). \\
\hline 617 & 58 & Carino, J. \& Colchester, M. From dams to development justice: progress with 'free, prior and \\
\hline 618 & & informed consent' since the World Commission on Dams. Water Alternatives 3, 423-437 \\
\hline 619 & & (2010). \\
\hline 620 & 59 & Chhatre, A. \& Agrawal, A. Trade-offs and synergies between carbon storage and livelihood \\
\hline 621 & & benefits from forest commons. Proc Natl \\
\hline 622 & & מ \\
\hline 623 & 60 & Kumar, K. \& Kerr, J. M. Territorialisation and marginalisation in the forested landscapes of \\
\hline 624 & & Orissa, India. Land Use Policy 30, 885-894, \\
\hline 625 & & doi:http://dx.doi.org/10.1016/j.landusepol.2012.06.015 (2013). \\
\hline 626 & 61 & Kothari, A., Corrigan, C., Jonas, H., Neumann, A. \& Shrumm, H. (Secretariat of the \\
\hline 627 & & Convention on Biological Diversity, CBD Technical Series No. 64, Montreal, Canada, 2012). \\
\hline 628 & 62 & Aldasoro, M. E. M. \& Argueto, A. V. Colecciones etnoentomológicas comunitarias: una \\
\hline 629 & & propuesta concpeutal y metodológica. Etnobiología \\
\hline 630 & 63 & Grieg-Gran, M. \& Gemmill-Herren, B. Handbook for participatory socioeconomic evaluation \\
\hline 631 & & \\
\hline 632 & & Rome, Italy. Online: http://www.fao.org/3/a-i2442e.pdf, 2012). \\
\hline 633 & 64 & Ingram, V. \& Njikeu, J. Sweet, Sticky, and Sustainable Social Business. Ecology c \\
\hline 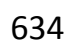 & & 8 Online: http://www.ecologyandsociety.org/vol16/iss11/art37/ (2011). \\
\hline
\end{tabular}


$63565 \quad$ Kremen, C., Iles, A. \& Bacon, C. Diversified Farming Systems: An Agroecological, Systems636 based Alternative to Modern Industrial Agriculture. Ecology and Society 17, 19 Online: http://dx.doi.org/10.5751/ES-05103-170444, doi:10.5751/es-05103-170444 (2012). Wittman, H., Desmarais, E. A. \& Wiebe, N. Food Sovereignty: Reconnecting Food, Nature and Community. (Food First Books, 2010).

641

67 Tengö, M. et al. Weaving knowledge systems in IPBES, CBD and beyond-lessons learned for sustainability. Current Opinion in Environmental Sustainability 26-27, 17-25,

642 doi:http://dx.doi.org/10.1016/j.cosust.2016.12.005 (2017).

643

644 


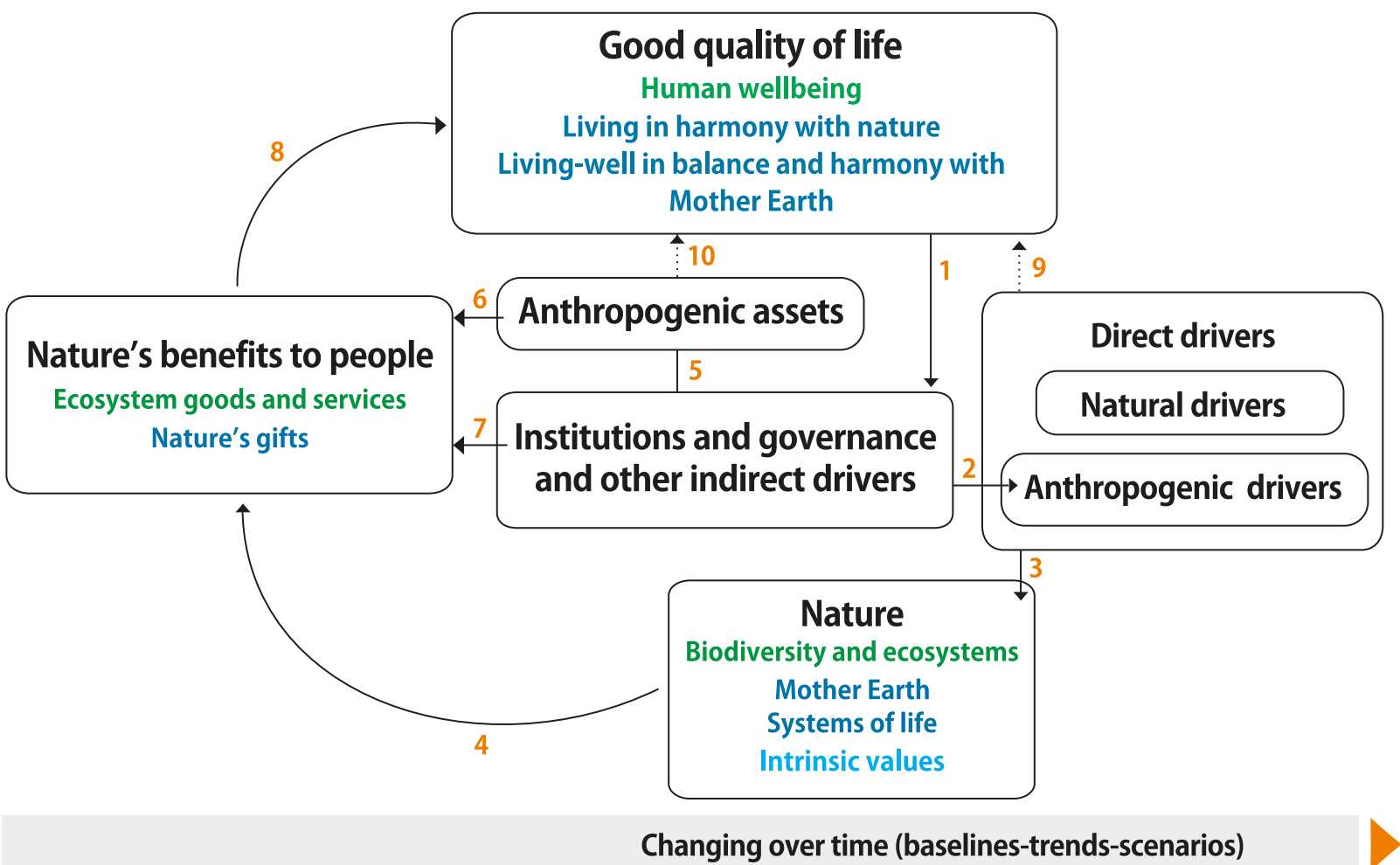




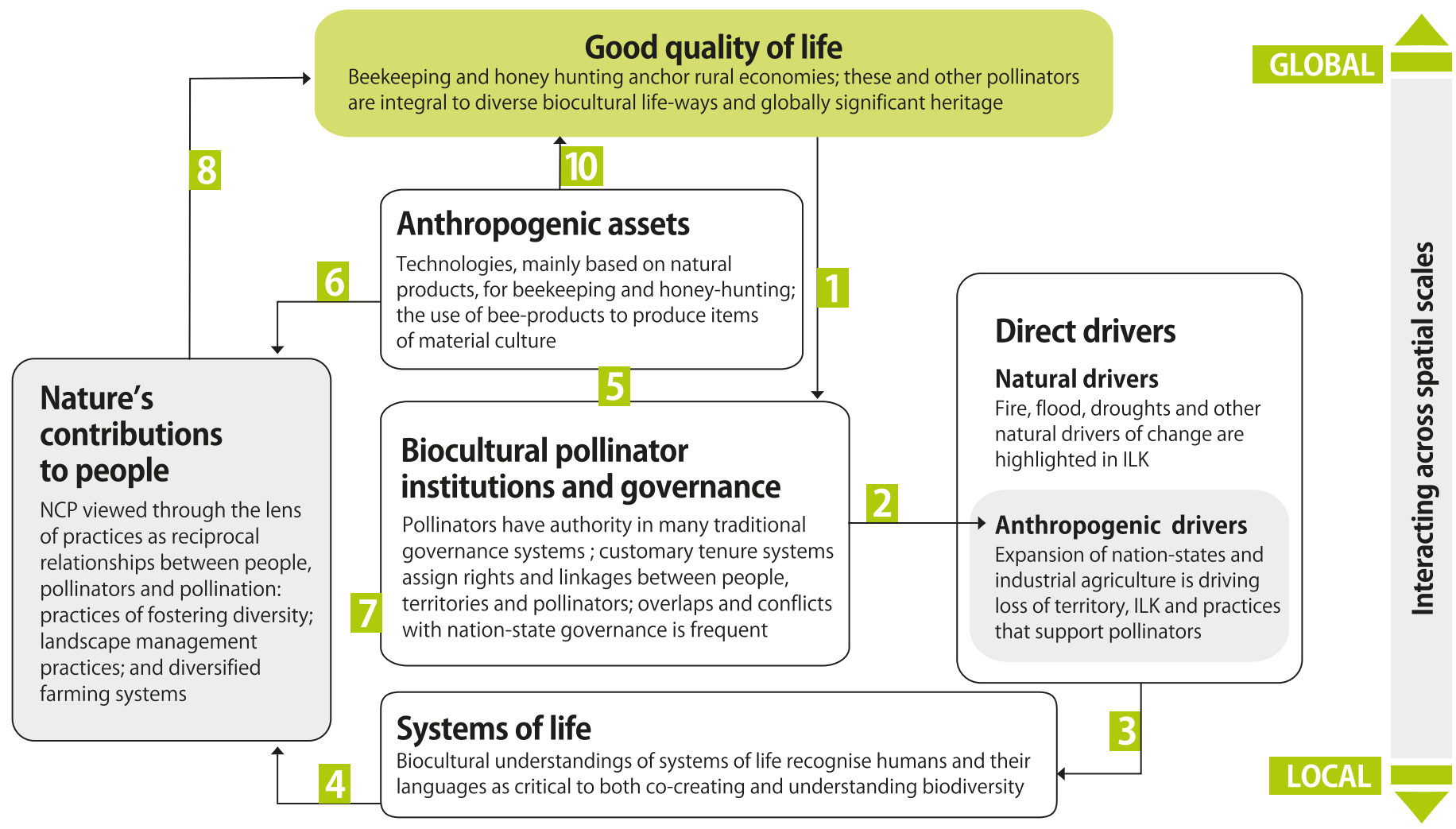

Changing over time (baselines-trends-scenarios) 


\section{a}

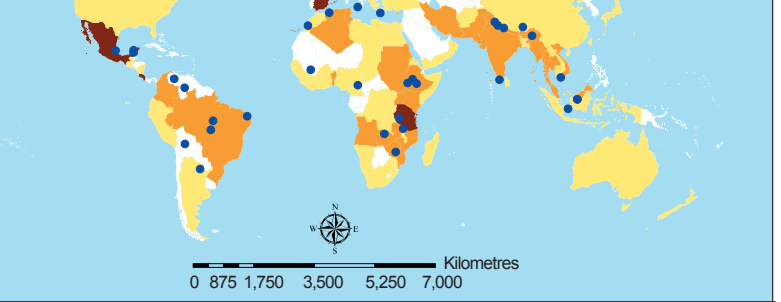

Beekeeping based on indigenous and/or local knowledge National compilations of information - number of studies in the analysis $12 \square 3$ or more

- Regional/local information - sites identified in the analysis

(c)

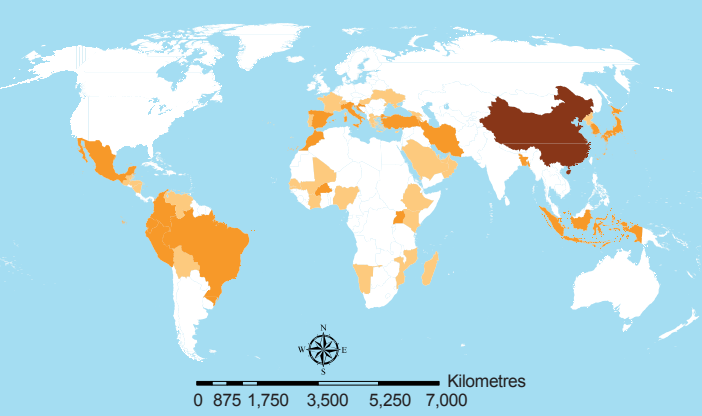

List of the Intangible Cultural Heritage of Humanity - countries with elements inscribed that celebrate and/or are dependent on pollinators and pollinator products

Number of elements inscribed

$1 \quad 2-5 \square 6$ or more

b)

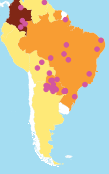

$\therefore$ is

1. $\because \therefore$

$\because \because$

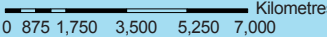

雨

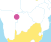

Honey hunting based on indigenous and/or local knowledge

National compilations of information - number of studies in the analysis

$\begin{array}{lll}1 & 2 & 3\end{array}$ or more

Regional/local information - sites identified in the analysis

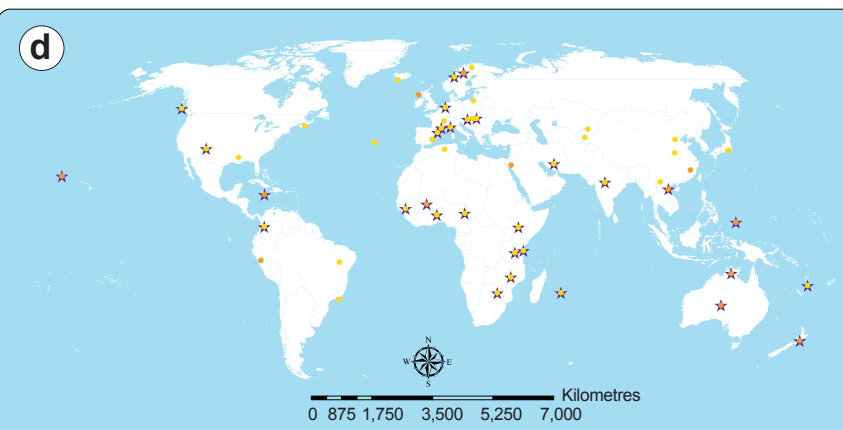

World Heritage List - sites inscribed that celebrate (through rock art) and/or protect pollinators and pollinator habitat

World Heritage - Mixed Sites

World Heritage - Cultural Sites

) Recognises the roles of indigenous peoples and/or local communities 


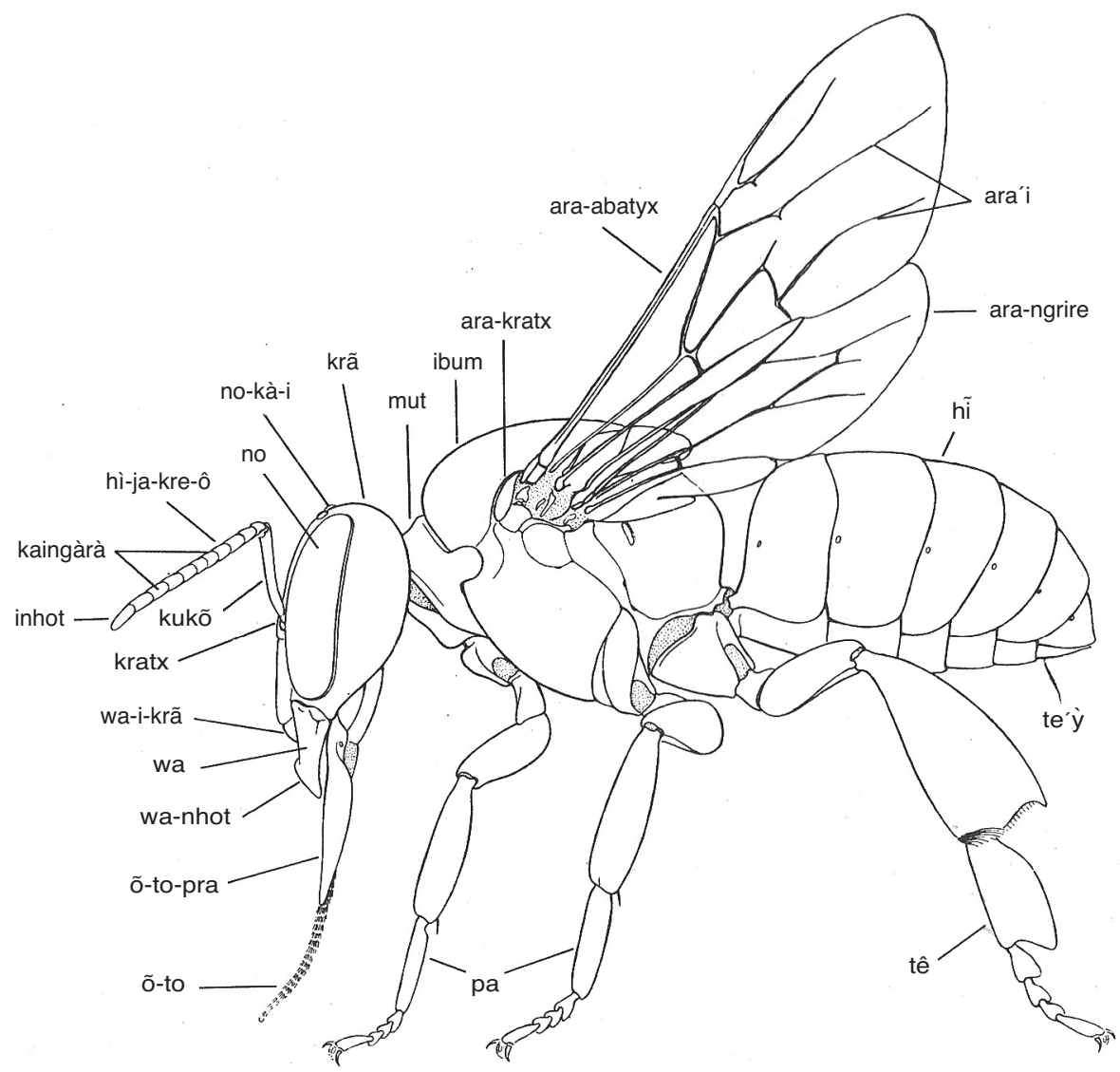




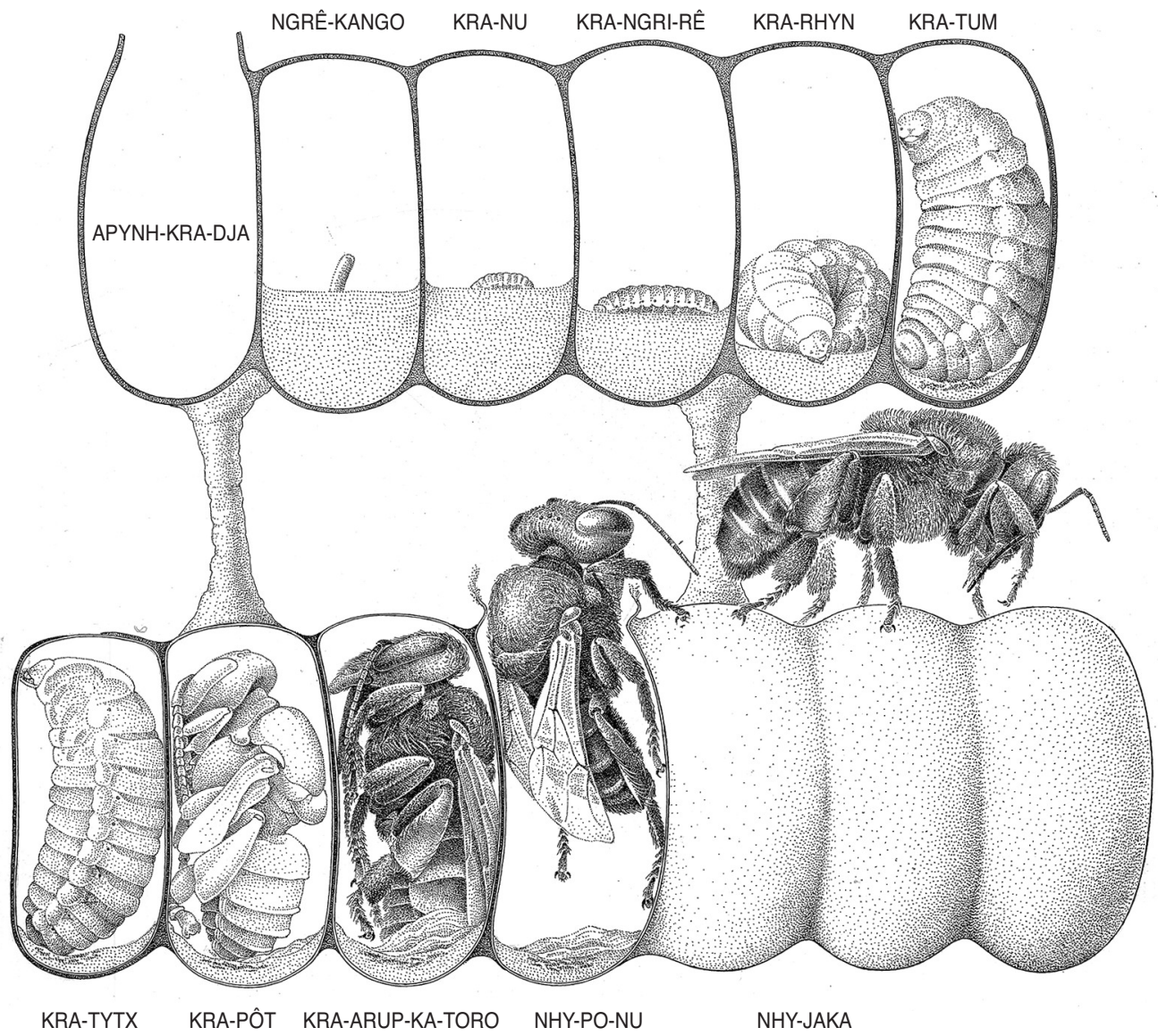


a

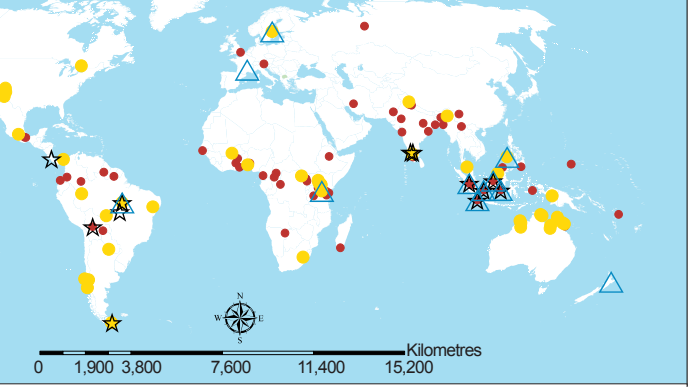

S Actions to foster pollinator nesting resources

* Mental maps of pollinators and pollinator resources

- Totemic and/or spiritual relationships between people and pollinators

- Taboos and traditions that protect pollinator habitat

(C)

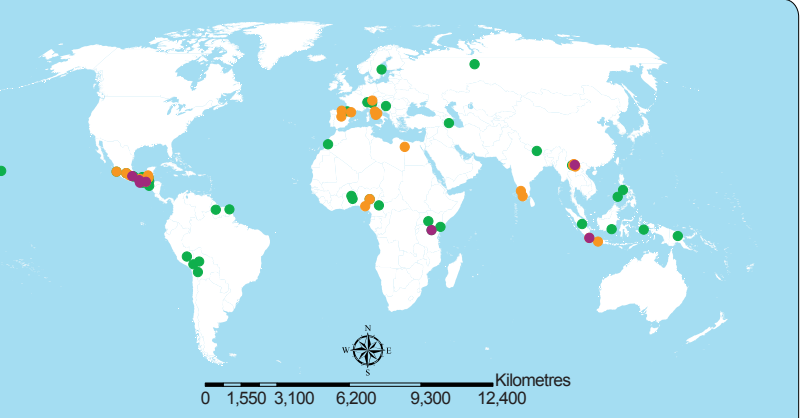

\section{Sites of diversified farming systems identified in the analysis}

- Commodity agroforestry that fosters pollinators and pollinator resources (e.g. shade coffee)

- Home gardens that foster pollinators and pollinator resources

- Shifting cultivation (seasonal rotation of crops, trees, animals and intercropping) that fosters pollination and pollinator resources b)

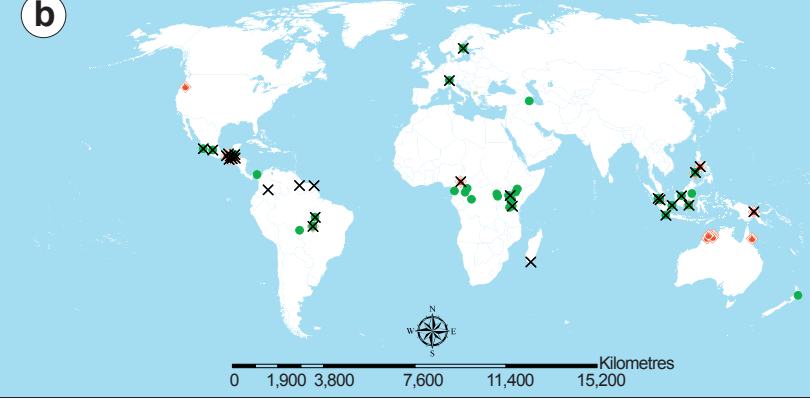

$\times$ Manipulation of pollinator resources in the landscape

- Use of biotemporal indicators to trigger management of pollinators and/or their resources

- Fire to stimulate pollinator resources

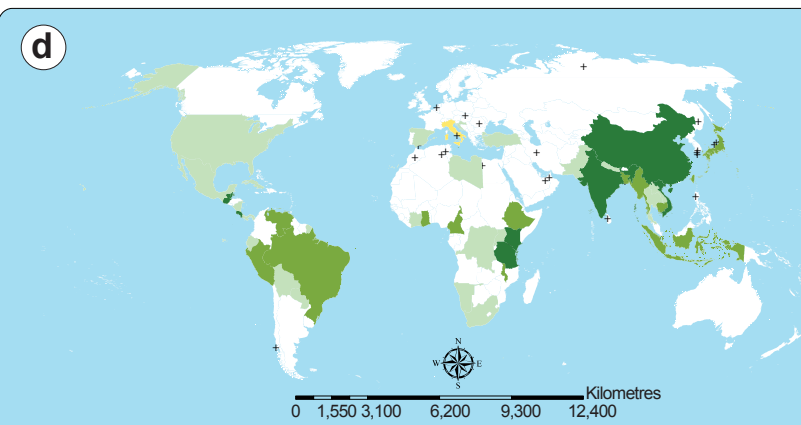

ش Globally Important Agricultural Heritage Systems - listed site of agricultural practices that foster pollinators and pollinator resource

Diversified farming systems - number of national compilations of evidence identified in the analysis

\begin{tabular}{l|l|l}
1 & 2 & 3 or more
\end{tabular}

